\title{
Co(II) and Cd(II) Complexes Derived from Heterocyclic Schiff-Bases: Synthesis, Structural Characterisation, and Biological Activity
}

\author{
Riyadh M. Ahmed, Enaam I. Yousif, and Mohamad J. Al-Jeboori \\ Department of Chemistry, College of Education, (Ibn Al-Haitham), University of Baghdad, P.O. Box 4150, Adhamiya, Baghdad, Iraq \\ Correspondence should be addressed to Mohamad J. Al-Jeboori; mohamadaljeboori@yahoo.com
}

Received 31 May 2013; Accepted 2 July 2013

Academic Editors: A. I. Matesanz and A. Souldozi

Copyright (C) 2013 Riyadh M. Ahmed et al. This is an open access article distributed under the Creative Commons Attribution License, which permits unrestricted use, distribution, and reproduction in any medium, provided the original work is properly cited.

\begin{abstract}
New monomeric cobalt and cadmium complexes with Schiff-bases, namely, $N^{\prime}-[(E)-(3-h y d r o x y-4-m e t h o x y p h e n y l) m e t h y l i-$ dene]furan-2-carbohydrazide $\left(\mathrm{L}^{1}\right)$ and $N^{\prime}-\left[(E)\right.$-(3-hydroxy-4-methoxyphenyl)methylidene]thiophene-2-carbohydrazide $\left(\mathrm{L}^{2}\right)$ are reported. Schiff-base ligands $\mathrm{L}^{1}$ and $\mathrm{L}^{2}$ were derived from condensation of 3-hydroxy-4-methoxybenzaldehyde (iso-vanillin) with furan-2-carboxylic acid hydrazide and thiophene-2-carboxylic acid hydrazide, respectively. Complexes of the general formula $\left[\mathrm{M}(\mathrm{L})_{2}\right] \mathrm{Cl}_{2}$ (where $\mathrm{M}=\mathrm{Co}(\mathrm{II})$ or $\mathrm{Cd}(\mathrm{II}), \mathrm{L}=\mathrm{L}^{1}$ or $\mathrm{L}^{2}$ ) have been obtained from the reaction of the corresponding metal chloride with the ligands. The ligands and their metal complexes were characterised by spectroscopic methods (FTIR, UV-Vis, ${ }^{1} \mathrm{H}$, and ${ }^{13} \mathrm{C}$ NMR spectra), elemental analysis, metal content, magnetic measurement, and conductance. These studies revealed the formation of four-coordinate complexes in which the geometry about metal ion is tetrahedral. Biological activity of the ligands and their metal complexes against gram positive bacterial strain Bacillus $(\mathrm{G}+)$ and gram negative bacteria Pseudomonas $\left(\mathrm{G}^{-}\right)$revealed that the metal complexes become less resistive to the microbial activities as compared to the free ligands.
\end{abstract}

\section{Introduction}

Schiff-base ligand is an interesting class of compounds which have played a key role in the development of coordination chemistry. Schiff-bases and their complexes have a variety of applications in the biological systems and industry [1-6]. Furthermore, Schiff-bases are very important materials for inorganic chemists as these are widely used in medicinal inorganic chemistry due to their diverse biological, pharmacological, antitumor activities and their excellent chelating ability. Schiff-bases have gained much importance in catalysis, biomimetic modelling applications, designing molecular magnet molecules, and in liquid crystals aspect [7-9]. Schiff-base ligands with heterocyclic molecule and/or containing heteroatoms such as $\mathrm{N}, \mathrm{O}$, and $\mathrm{S}$ show a broad biological activity and are of special interest because of the variety of ways in which they are interacted to transition metal ions [10, 11]. Experimental studies related to DNA binding and cleavage were explored using a range of potent $\mathrm{Cu}$ (II) Schiff-base complexes. In addition, Schiff-base nickel(II) complexes have been regarded as models for enzymes such as urease [12]. Vanilline and furfurylamine Schiff-base derivatives are very useful biochemical materials having biological activities $[13,14]$. Structural characterisation of Schiff-bases and their metal complexes are well documented, including X-ray molecular structure [15-19]. In this paper, we report the synthesis of new Schiff-bases $\mathrm{L}^{1}$ and $\mathrm{L}^{2}$, namely, $N^{\prime}-[(E)-(3$-hydroxy-4-methoxyphenyl)methylidene]furan-2-carbohydrazide and $N^{\prime}$-[(E)-(3hydroxy-4-methoxyphenyl)methylidene]thiophene-2-carbohydrazide, respectively, and their metal complexes with $\mathrm{Co}(\mathrm{II})$ and $\mathrm{Cd}(\mathrm{II})$ ions.

\section{Experimental}

2.1. Materials. All reagents were commercially available and used without further purification. Solvents were distilled from appropriate drying agents immediately prior to use. 
TABLE 1: Colours, yields, elemental analyses and molar conductance values.

\begin{tabular}{|c|c|c|c|c|c|c|c|c|c|}
\hline \multirow{2}{*}{ Compound } & \multirow{2}{*}{ Colour } & \multirow{2}{*}{ Yield (\%) } & \multirow{2}{*}{$\mathrm{m} \cdot \mathrm{p}$} & \multicolumn{5}{|c|}{ Found (Calc.) (\%) } & \multirow{2}{*}{$\Lambda_{\mathrm{M}}\left(\mathrm{cm}^{2} \Omega^{-1} \mathrm{~mol}^{-1}\right)$} \\
\hline & & & & M & $\mathrm{C}$ & $\mathrm{H}$ & $\mathrm{N}$ & $\mathrm{Cl}$ & \\
\hline$\overline{\mathrm{L}^{1}}$ & Pale-yellow & 54 & 183 & - & $58.97(60.00)$ & $4.47(4.65)$ & $10.39(10.76)$ & - & - \\
\hline$\left[\mathrm{Co}^{\mathrm{II}}\left(\mathrm{L}^{1}\right)_{2}\right] \mathrm{Cl}_{2}$ & Pale-green & 55 & 216 & $8.12(9.06)$ & $47.49(48.02)$ & $3.48(3.72)$ & $8.21(8.62)$ & $9.55(10.90)$ & 70.2 \\
\hline$\left[\mathrm{Cd}^{\mathrm{II}}\left(\mathrm{L}^{1}\right)_{2}\right] \mathrm{Cl}_{2}$ & Yellow & 46 & 288 & $14.20(15.97)$ & $43.78(44.37)$ & $3.19(3.44)$ & $7.77(7.96)$ & $9.12(10.07)$ & 71.4 \\
\hline $\mathrm{L}^{2}$ & Orange-yellow & 65 & 170 & - & $55.76(56.51)$ & $4.08(4.38)$ & $9.85(10.14)$ & - & - \\
\hline$\left[\mathrm{Co}^{\mathrm{II}}\left(\mathrm{L}^{2}\right)_{2}\right] \mathrm{Cl}_{2}$ & Light-orange & 57 & 196 & $8.10(8.64)$ & $45.13(45.76)$ & $3.27(3.54)$ & $7.84(8.21)$ & $8.89(10.39)$ & 78.1 \\
\hline$\left[\mathrm{Cd}^{\mathrm{II}}\left(\mathrm{L}^{2}\right)_{2}\right] \mathrm{Cl}_{2}$ & Deep-yellow & 43 & 270 & $14.04(15.27)$ & $42.09(42.43)$ & $3.12(3.29)$ & $7.28(7.61)$ & $8.54(9.63)$ & 75.3 \\
\hline
\end{tabular}

2.2. Physical Measurements. Melting points were obtained on a Buchi SMP-20 capillary melting point apparatus and are uncorrected. FTIR spectra were recorded as $\mathrm{KBr}$ disc using a Shimadzu 8400 FTIR spectrophotometer in the range $4000-400 \mathrm{~cm}^{-1}$. Electronic spectra of the prepared compounds were measured in the region $250-1100 \mathrm{~nm}$ for $10^{-3} \mathrm{M}$ solutions in DMSO at $25^{\circ} \mathrm{C}$ using a Shimadzu 160 spectrophotometer with $1.000 \pm 0.001 \mathrm{~cm}^{-1}$ matched quartz cell. ${ }^{1} \mathrm{H}$ and ${ }^{13} \mathrm{C}$ NMR spectra were acquired in DMSO$\mathrm{d}_{6}$ solution using a Brucker AMX $400 \mathrm{MHz}$ spectrometer with tetramethylsilane (TMS) as an internal standard for ${ }^{1} \mathrm{H}$ NMR. Metals were determined using a Shimadzu (A.A) $680 \mathrm{G}$ atomic absorption spectrophotometer. Chloride was determined using potentiometer titration method on a 686Titroprocessor, 665 Dosimat Metrohm, Swiss. Conductivity measurements were made with DMSO solutions using a PW 9526 digital conductivity meter and room temperature magnetic moments were measured with a magnetic susceptibility balance (Johnson Matthey Catalytic System Division).

\section{Synthesis}

3.1. Preparation of $N^{\prime}-[(E)-(3-H y d r o x y-4-m e t h o x y p h e n-$ $y l$ methylidene]furan-2-carbohydrazide $\left(L^{1}\right)$. A solution of 3-hydroxy-4-methoxy-benzaldehyde (1.00 g, $6.572 \mathrm{mmoL})$ in methanol $(5 \mathrm{~mL})$ was added to a mixture of furan-2carboxylic acid hydrazide $(0.644 \mathrm{~g}, 6.572 \mathrm{mmoL})$ in methanol $(5 \mathrm{~mL})$, and then (2-4) drops of glacial acetic acid was added. The reaction mixture was refluxed for $4 \mathrm{~h}$, filtered off, and then cooled to RT. Solvent was allowed to slow evaporation and a pale yellow solid was obtained. Yield (0.93 g, 54\%), $\mathrm{m} . \mathrm{p}=183^{\circ} \mathrm{C}$. IR data $\left(\mathrm{cm}^{-1}\right): 3473 v(\mathrm{O}-\mathrm{H}), 3202 v(\mathrm{~N}-\mathrm{H})$, $1664 \nu(\mathrm{C}=\mathrm{O}), 1629 \nu(\mathrm{C}=\mathrm{N}) . \mathrm{NMR}$ data $(\mathrm{ppm}),{ }^{1} \mathrm{H}$ NMR data showed peaks at $\delta_{\mathrm{H}}\left(400 \mathrm{MHz}, \mathrm{DMSO}-\mathrm{d}_{6}\right): 3.84(3 \mathrm{H}$, s, $\left.\mathrm{CH}_{3}\right), 6.92(\mathrm{H}, \mathrm{NH}), 7.214-7.340(3 \mathrm{H}, \mathrm{Ar}-\mathrm{H}), 7.85-7.911$ $(3 \mathrm{H}, \mathrm{Ar}-\mathrm{H}), 8.57(1 \mathrm{H}, \mathrm{s}, \mathrm{O}-\mathrm{H}), 8.74(1 \mathrm{H}, \mathrm{s}, \mathrm{H}-\mathrm{C}=\mathrm{N}) .{ }^{13} \mathrm{C}$ NMR data showed peaks at $\delta_{c}\left(100.63 \mathrm{MHz}, \mathrm{DMSO}-\mathrm{d}_{6}\right)$ : $56.51\left(\mathrm{O}-\mathrm{CH}_{3}\right),(146.09 ; 109.41 ; 111.16$ and 147.24$)$ assigned to carbon of furan ring, $(122.68 ; 115.05 ; 126.53 ; 148.51 ; 112.48$ and $115.92)$ assigned to aromatic ring carbon, $149.50(\mathrm{HC}=\mathrm{N})$, $154.51(\mathrm{C}=\mathrm{O})$.

3.2. Preparation of $N^{\prime}-[(E)-(3-H y d r o x y-4-m e t h o x y p h e n-$ yl)methylidene] thiophene-2-carbohydrazide $\left(L^{2}\right)$. The method used to prepare $\mathrm{L}^{2}$ was similar to that used for $\mathrm{L}^{1}$ but thiophene-2-carboxylic acid hydrazide (1.00 g, $0.007 \mathrm{mmoL}$ ) was used in place of furan-2-carboxylic acid hydrazide. The quantities of other reagents used were adjusted accordingly. An identical work-up procedure gave the title compound as an orange-yellow solid. Yield $(1.27 \mathrm{~g}, 65 \%)$, m.p. $=170^{\circ} \mathrm{C}$. IR data $\left(\mathrm{cm}^{-1}\right): 3375 v(\mathrm{O}-\mathrm{H}), 3163 v(\mathrm{~N}-\mathrm{H}), 1669 v(\mathrm{C}=\mathrm{O}), 1618$ $\nu(\mathrm{C}=\mathrm{N})$. NMR data $(\mathrm{ppm}), \delta_{\mathrm{H}}\left(400 \mathrm{MHz}, \mathrm{DMSO}-\mathrm{d}_{6}\right): 3.83$ $\left(3 \mathrm{H}, \mathrm{s}, \mathrm{CH}_{3}\right), 6.69(\mathrm{H}, \mathrm{NH}), 6.83-6.95(3 \mathrm{H}, \mathrm{Ar}-\mathrm{H}), 7.06-7.40$ $(3 \mathrm{H}, \mathrm{Ar}-\mathrm{H}), 7.92(\mathrm{H}, \mathrm{s}, \mathrm{O}-\mathrm{H}), 8.34(\mathrm{H}-\mathrm{C}=\mathrm{N}-) .{ }^{13} \mathrm{C} \mathrm{NMR}$ data $\delta_{c}\left(100.63 \mathrm{MHz}, \mathrm{DMSO}-\mathrm{d}_{6}\right): 56.30\left(\mathrm{O}-\mathrm{CH}_{3}\right),(129.59$; $128.65 ; 129.59$; and 137.70$)$ assigned to carbon of furan ring, (116.11; 124.50; 125.37; 123.09; 132.18 and 148.58) assigned to aromatic ring carbon, $161.34(\mathrm{C}=\mathrm{O}), 151.86(\mathrm{H}-\mathrm{C}=\mathrm{N})$.

3.3. General Synthesis of Complexes. A methanolic solution $(10 \mathrm{~mL})$ of the hydrated metal salt $(1 \mathrm{mmoL}), \mathrm{MCl}_{2} \cdot \mathrm{XH}_{2} \mathrm{O}$ (where $\mathrm{M}=\mathrm{Co}^{\mathrm{II}} ; \mathrm{X}=6 ; \mathrm{Cd}^{\mathrm{II}} ; \mathrm{X}=2$ ), was stirred into methanolic solution of the Schiff-base ligand $(2 \mathrm{mmoL})$ in methanol $(15 \mathrm{~mL})$. The reaction mixture was then refluxed for $2 \mathrm{~h}$ to give a coloured precipitate which was collected by filtration, washed with cold ethanol $(5 \mathrm{~mL})$, and dried at room temperature. Elemental analysis data, colours, and yields for the complexes are given in Table 1 .

3.4. Determination of Bacteriological Activity. Bioactivities were investigated using agar-well diffusion method [20]. The wells were dug in the media with the help of a sterile metallic borer with centers at least $24 \mathrm{~mm}$. Recommended concentration $(100 \mu \mathrm{L})$ of the test sample $1 \mathrm{mg} / \mathrm{mL}$ in DMSO was introduced in the respective wells. The plates were incubated immediately at $37^{\circ} \mathrm{C}$ for $20 \mathrm{~h}$. Activity was determined by measuring the diameter of zones showing complete inhibition ( $\mathrm{mm})$. In order to clarify the role of DMSO in the biological screening, separate studies were carried out with the solutions alone of DMSO and they showed no activity against any bacterial strains. Ligand found to be potentially active against these bacterial strains were compared with its complexes.

\section{Results and Discussion}

4.1. Chemistry. The reaction of 3-hydroxy-4-methoxybenzaldehyde with furan-2-carboxylic acid hydrazide or thiophene-2-carboxylic acid hydrazide in mole ratio $1: 1$ gave $\mathrm{L}^{1}$ and $\mathrm{L}^{2}$, respectively (Scheme 1 ). The Schiff-bases were characterised by elemental analysis (Table 1), IR (Table 2), UV-Vis spectroscopy (Table 3 ) and ${ }^{1} \mathrm{H}$-, and 


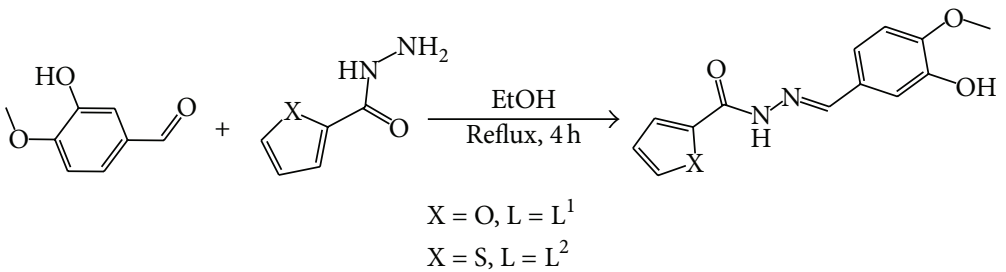

Scheme 1: Synthesis diagram of the Schiff-base ligands $\left(\mathrm{L}^{1}\right.$ and $\left.\mathrm{L}^{2}\right)$.

TABLE 2: IR frequencies $\left(\mathrm{cm}^{-1}\right)$ of the compounds.

\begin{tabular}{|c|c|c|c|c|c|c|c|c|c|}
\hline Compound & $v(\mathrm{O}-\mathrm{H})$ & $\nu(\mathrm{N}-\mathrm{H})$ & $\nu(\mathrm{C}=\mathrm{O})$ & $\nu(\mathrm{C}=\mathrm{N})$ & $v(\mathrm{C}-\mathrm{O})$ & $v(\mathrm{C}-\mathrm{S})$ & $v\left(\mathrm{O}-\mathrm{CH}_{3}\right)$ & $v(\mathrm{M}-\mathrm{O})$ & $v(\mathrm{M}-\mathrm{N})$ \\
\hline $\mathrm{L}^{1}$ & 3473 & 3203 & 1664 & 1629 & 1271 & - & 1157 & - & - \\
\hline$\left[\mathrm{Co}^{\mathrm{II}}\left(\mathrm{L}^{1}\right)_{2}\right] \mathrm{Cl}_{2}$ & 3529 & 3404 & 1641 & 1600 & 1257 & - & 1124 & 619 & 549 \\
\hline$\left[\mathrm{Cd}^{\mathrm{II}}\left(\mathrm{L}^{1}\right)_{2}\right] \mathrm{Cl}_{2}$ & 3450 & 3226 & 1643 & 1613 & 1263 & - & 1126 & 698 & 540 \\
\hline $\mathrm{L}^{2}$ & 3375 & 3163 & 1669 & 1618 & 1265 & 846,1361 & 1134 & - & - \\
\hline$\left[\mathrm{Co}^{\mathrm{II}}\left(\mathrm{L}^{2}\right)_{2}\right] \mathrm{Cl}_{2}$ & 3448 & 3147 & 1647 & 1603 & 1203 & 817,1303 & 1147 & 650 & 404 \\
\hline$\left[\mathrm{Cd}^{\mathrm{II}}\left(\mathrm{L}^{2}\right)_{2}\right] \mathrm{Cl}_{2}$ & 3373 & 3209 & 1649 & 1608 & 1223 & 844,1342 & 1149 & 678 & 416 \\
\hline
\end{tabular}

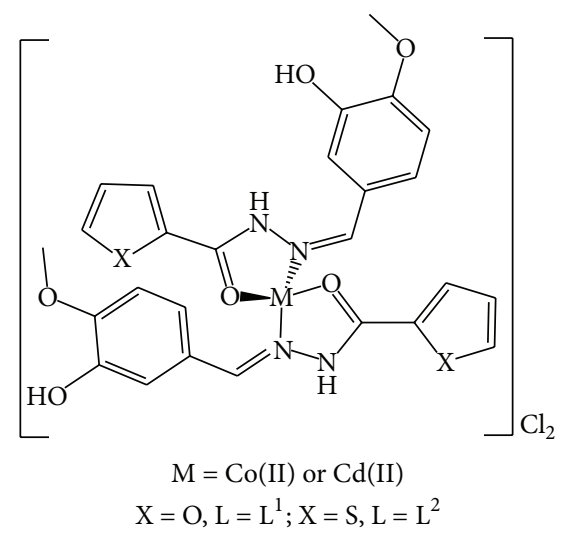

Scheme 2: Proposed structure of complexes.

${ }^{13} \mathrm{C}-\mathrm{NMR}$ spectra. The dielectrolyte metal-complexes were synthesised by mixing at reflux 2 mmole of the Schiff-base ligand with $1 \mathrm{mmole}$ of the appropriate metal chloride. Monomeric complexes of the general formulae $\left[\mathrm{M}(\mathrm{L})_{2}\right]^{+2}$ (where $\mathrm{M}=\mathrm{Co}^{\mathrm{II}}$ and $\mathrm{Cd}^{\mathrm{II}}$ ) were obtained (Scheme 2 ). The complexes are air-stable solids, soluble in DMSO and DMF. The complexes are sparingly soluble in $\mathrm{MeOH}$ and not soluble in other common organic solvents. The coordination geometries of the complexes were deduced from their spectra. The analytical data (Table 1) agree well with the suggested formulae. Conductivity measurements of the complexes in DMSO solutions lie in the $71.4-78.1 \mathrm{~cm}^{2} \Omega^{-1} \mathrm{~mol}^{-1}$ range, indicating their 1:2 electrolytic behaviour (Table 1) [21].

4.2. FTIR and NMR Spectra. The important infrared bands for the ligands and their complexes together with their assignments are listed in (Table 2). The IR spectra of the ligands show characteristic bands at 1664-1669 and $1629-1618 \mathrm{~cm}^{-1}$ due to the $v(\mathrm{C}=\mathrm{O}), v(\mathrm{C}=\mathrm{N})$ functional groups, respectively. The bands at 3473,3203 , and $3375,3163 \mathrm{~cm}^{-1}$ assigned to the
$\nu(\mathrm{O}-\mathrm{H})$ and $\nu(\mathrm{N}-\mathrm{H})$ stretching group for ligands $\mathrm{L}^{1}$ and $\mathrm{L}^{2}$, respectively, [22-24]. The IR spectra of the complexes exhibited ligand bands with the appropriate shifts due to complex formation (Table 2). The $v(\mathrm{C}=\mathrm{O})$ and $v(\mathrm{C}=\mathrm{N})$ stretching bands that appeared in the free ligands at ca. 1660 and $1620 \mathrm{~cm}^{-1}$, respectively, are shifted to lower frequency in the complexes and observed in the ranges $1641-1649 \mathrm{~cm}^{-1}$ and $1600-1613 \mathrm{~cm}^{-1}$ for $\nu(\mathrm{C}=\mathrm{O})$ and $\nu(\mathrm{C}=\mathrm{N})$, respectively. These bands are assigned to a $v(\mathrm{C}=\mathrm{O})$ and $v(\mathrm{C}=\mathrm{N})$ stretches of reduced bond order. This can be attributed to delocalisation of metal electron density $\left(t_{2 g}\right)$ to the $\pi$-system of the ligand $[25,26]$, indicating coordination of oxygen of $\mathrm{C}=\mathrm{O}$ and nitrogen of the $\mathrm{C}=\mathrm{N}$ moieties to the metal atoms [27]. The bands of $v(\mathrm{C}-\mathrm{O})$ at ca. $1270 \mathrm{~cm}^{-1}$ in the free ligands are shifted to lower frequencies and appeared at $1203-1263 \mathrm{~cm}^{-1}$ for the complexes. At lower frequency the complexes exhibited bands around 540-549 and $404-416 \mathrm{~cm}^{-1}$ which could be assigned to $\nu(\mathrm{M}-\mathrm{O})$ and $\nu(\mathrm{M}-\mathrm{N})$ vibration mode [25]. These bands indicated that the imine, nitrogens and the oxygen of carbonyl group of the ligands are involved in coordination with metal ion. The IR spectra of the complexes show peaks in the range 3373-3529 and around 3203-3404 $\mathrm{cm}^{-1}$ assigned for the free $\mathrm{O}-\mathrm{H}$ and $\mathrm{N}-\mathrm{H}$ functional groups.

${ }^{1} \mathrm{H},{ }^{13} \mathrm{C}$ NMR spectra of $\mathrm{L}^{1}$ and $\mathrm{L}^{2}$ show the expected signals (see Section 2). ${ }^{1} \mathrm{H}$ NMR of the ligands show peaks at chemical shift ca. $3.84 \mathrm{ppm}$. This singlet peak with three proton integration has been assigned to the methyl moiety of the methoxy group $\left(3 \mathrm{H}, \mathrm{s}, \mathrm{CH}_{3}\right)$. As expected this signal appeared downfield. The chemical shift for the $\mathrm{O}-\mathrm{H}$ group was observed at 8.57 and 7.92 ppm for $\mathrm{L}^{1}$ and $\mathrm{L}^{2}$, respectively. The deshielding of this group and shifted downfield may be due to hydrogen bonding to the NMR solvent, which lead to decrease of the density of electrons on the hydroxyl group. Signals at 7.0-7.4 ppm were assigned to protons of aromatic ring. The chemical shift at 8.74 and $8.34 \mathrm{ppm}$ in $\mathrm{L}^{1}$ and $\mathrm{L}^{2}$, respectively assigned to $-\mathrm{CH}=\mathrm{N}-$ (imine) protons. 
TABLE 3: U.V-Vis spectral data in DMSO solutions.

\begin{tabular}{|c|c|c|c|c|}
\hline Compound & $\mu_{\mathrm{eff}}(\mathrm{BM})$ & Band position $(\lambda \mathrm{nm})$ & $\begin{array}{l}\text { Extinction coefficient } \\
\varepsilon_{\max }\left(\mathrm{dm}^{3} \mathrm{~mol}^{-1} \mathrm{~cm}^{-1}\right)\end{array}$ & Assignments \\
\hline \multirow{3}{*}{$\mathrm{L}^{1}$} & & 270 & 3773 & $\pi \rightarrow \pi^{*}$ \\
\hline & & 376 & 147 & $n \rightarrow \pi^{*}$ \\
\hline & & 269 & 2797 & $\pi \rightarrow \pi^{*}$ \\
\hline \multirow[t]{2}{*}[\mathrm{Co}^{\mathrm{II}}(\mathrm{L}^{1})_{2}]{$\mathrm{Cl}_{2}$} & 3.91 & 490 & 75 & ${ }^{4} \mathrm{~T}_{1} \mathrm{~g}^{(\mathrm{F})} \rightarrow{ }^{4} \mathrm{~T}_{1} \mathrm{~g}^{(\mathrm{P})}$ \\
\hline & & 674 & 91 & ${ }^{4} \mathrm{~T}_{1} \mathrm{~g}^{(\mathrm{F})} \rightarrow{ }^{4} \mathrm{~A}_{2} \mathrm{~g}^{(\mathrm{F})}$ \\
\hline \multirow{2}{*}[\mathrm{Cd}^{\mathrm{II}}(\mathrm{L}^{1})_{2}]{$\mathrm{Cl}_{2}$} & & 294 & 587 & $\pi \rightarrow \pi^{*}$ \\
\hline & & 330 & 682 & CT \\
\hline \multirow{3}{*}{$\mathrm{L}^{2}$} & & 261 & 3577 & $\pi \rightarrow \pi^{*}$ \\
\hline & & 314 & 2466 & $n \rightarrow \pi^{*}$ \\
\hline & & 270 & 3737 & $\pi \rightarrow \pi^{*}$ \\
\hline \multirow[t]{2}{*}[\mathrm{Co}^{\mathrm{II}}(\mathrm{L}^{2})_{2}]{$\mathrm{Cl}_{2}$} & 3.87 & 424 & 154 & ${ }^{4} \mathrm{~T}_{1} \mathrm{~g}^{(\mathrm{F})} \rightarrow{ }^{4} \mathrm{~T}_{1} \mathrm{~g}^{(\mathrm{P})}$ \\
\hline & & 633 & 147 & ${ }^{4} \mathrm{~T}_{1} \mathrm{~g}^{(\mathrm{F})} \rightarrow{ }^{4} \mathrm{~A}_{2} \mathrm{~g}^{(\mathrm{F})}$ \\
\hline \multirow{2}{*}[\mathrm{Cd}^{\mathrm{II}}(\mathrm{L}^{2})_{2}]{$\mathrm{Cl}_{2}$} & & 269 & 888 & $\pi \rightarrow \pi^{*}$ \\
\hline & & 302 & 1601 & CT \\
\hline
\end{tabular}

4.3. Electronic Spectra and Magnetic Moment Measurements. The UV-Vis spectrum of $\mathrm{L}^{1}$ exhibits a high intense absorption peak at $376 \mathrm{~nm}$, with a shoulder at $270 \mathrm{~nm}$, assigned to $\mathrm{n}$ $\rightarrow \pi^{*}$ and $\pi \rightarrow \pi^{*}$, respectively [28]. The spectrum for $\mathrm{L}^{2}$ exhibits a high intense absorption peak at $314 \mathrm{~nm}$, with a shoulder at $261 \mathrm{~nm}$, assigned to $\mathrm{n} \rightarrow \pi^{*}$ and $\pi \rightarrow \pi^{*}$, respectively. The electronic spectra of the cobalt(II) complex for 1 and 2 exhibit high intense peaks at 269 and $270 \mathrm{~nm}$, respectively, due to ligand field. The absorption bands at 390 and $414 \mathrm{~nm}$ for 1 and 2, respectively, attributed to ${ }^{4} \mathrm{~T}_{1} \mathrm{~g}^{(\mathrm{F})} \rightarrow{ }^{4} \mathrm{~T}_{1} \mathrm{~g}^{(\mathrm{P})}$ transitions. The spectra of the Co(II) complex for 1 and 2 exhibited band which can be attributed to ${ }^{4} \mathrm{~T}_{1} \mathrm{~g}^{(\mathrm{F})} \rightarrow{ }^{4} \mathrm{~A}_{1} \mathrm{~g}^{(\mathrm{F})}$ transition, corresponding to tetrahedral Co(II) complexes [29-32]. The observed room temperature magnetic moment values 3.91 and 3.87 B.M for $\mathrm{L}^{1}$ and $\mathrm{L}^{2}$ Co-complexes, respectively confirmed their tetrahedral geometry. The slightly lower magnetic moment might be due to the slight deviation from the regular tetrahedral geometry. The spectra of the Cd(II) complex for 1 and 2 exhibited bands assigned to ligand $\pi \rightarrow \pi^{*}$ and $\mathrm{L} \rightarrow \mathrm{M}$ charge transfer $[29,33]$. The metal normally prefers tetrahedral coordination.

\section{Antimicrobial Activity}

The free Schiff-base ligands and their metal complexes were screened against Bacillus (G+) and E. coli (G-) to assess their potential as an antimicrobial agent by disc diffusion method. The measured zone of inhibition against the growth of various microorganisms is listed in Table 4 . It is found that the ligand has higher antimicrobial activity than its metal complexes. This can be explained as follows. The biological activity of the Schiff-base ligand is related to the imine moiety, which plays a key role in the inhibition of the tested bacteria. The lower antimicrobial activity of the metal complexes compared with that in the ligand may be due to the strong
TABLE 4: Antibacterial activities of the synthesised Schiff-bases and metal complexes.

\begin{tabular}{lcc}
\hline Compounds & Bacillus $(\mathrm{G}+)$ & E. coli $(\mathrm{G}-)$ \\
\hline $\mathrm{L}^{1}$ & ++ & +++ \\
{$\left[\mathrm{Co}^{\mathrm{II}}\left(\mathrm{L}^{1}\right)_{2}\right] \mathrm{Cl}_{2}$} & + & + \\
{$\left[\mathrm{Cd}^{\mathrm{II}}\left(\mathrm{L}^{1}\right)_{2}\right] \mathrm{Cl}_{2}$} & - & + \\
$\mathrm{L}^{2}$ & + & ++ \\
{$\left[\mathrm{Co}^{\mathrm{II}}\left(\mathrm{L}^{2}\right)_{2}\right] \mathrm{Cl}_{2}$} & + & - \\
{$\left[\mathrm{Cd}^{\mathrm{II}}\left(\mathrm{L}^{2}\right)_{2}\right] \mathrm{Cl}_{2}$} & - & - \\
\hline
\end{tabular}

${ }^{-}:$No inhibition $=$inactive, ${ }^{+}:(2-4) \mathrm{mm}=$ active, ${ }^{++}:(5-7) \mathrm{mm}=$ more active, ${ }^{+++}:(8-13) \mathrm{mm}=$ highly active.

interaction between the imine moieties and the metal ions. Such interaction will reduce the activity of the imine moiety in the inhibition.

\section{Conclusion}

In this paper, we have explored the synthesis and coordination chemistry of cobalt and cadmium complexes derived from the Schiff-base ligands $\mathrm{L}^{1}$ and $\mathrm{L}^{2}$. The complexes were prepared by mixing at reflux 2 mmole of the Schiffbase ligand with 1 mmole of the appropriate metal chloride. Complexes of the general formulae $\left[\mathrm{M}(\mathrm{L})_{2}\right] \mathrm{Cl}_{2}$ (where $\mathrm{M}=$ $\mathrm{Co}(\mathrm{II})$ and $\mathrm{Cd}(\mathrm{II}) ; \mathrm{L}=\mathrm{L}^{1}$ and $\mathrm{L}^{2}$ ) were obtained. Physicochemical analysis indicated the formation of four coordinate dicationic metal complexes. Biological activities revealed that the ligands have higher antimicrobial activity than their metal complexes.

\section{References}

[1] W.-L. Liu, Y. Zou, C.-L. Ni, Y.-Z. Li, and Q.-J. Meng, "Synthesis, structural characterization and magnetic properties of 
new tripeptide Schiff base heterotrinuclear $\mathrm{Cu}(\mathrm{II})-\mathrm{M}$ (II)-Cu(II) $(\mathrm{M}=\mathrm{Ni}$ and $\mathrm{Mn})$ complexes," Journal of Molecular Structure, vol. 751, no. 1-3, pp. 1-6, 2005.

[2] P. Przybylski, G. Schroeder, and B. Brzezinski, "Complexes of Schiff base of gossypol with 5-hydroxy-3-oxapentylamine and $\mathrm{Ca}^{2+}, \mathrm{Ba}^{2+}$ or $\mathrm{Pb}^{2+}$ cations studied by NMR, FT-IR, ESI MS as well as PM5 semiempirical methods," Journal of Molecular Structure, vol. 658, no. 1-2, pp. 115-124, 2003.

[3] R. Dreos, G. Nardin, L. Randaccio, P. Siega, G. Tauzher, and V. Vrdoljak, "Synthesis, molecular structure, and characterization in solution of a new series of inorganic and organometallic Co(III) Schiff base complexes," Inorganica Chimica Acta, vol. 349, pp. 239-248, 2003.

[4] K. V. Shuvaev, L. N. Dawe, and L. K. Thompson, "A Mn ${ }_{12}^{\mathrm{II}}$ supramolecular array with four independent spin," European Journal of Inorganic Chemistry, no. 29, pp. 4583-4586, 2010.

[5] M. D. Cohen and S. Flavian, "Topochemistry. Part XXIV. The luminescence properties of $N$-salicylideneaniline and related anils in solution," Journal of the Chemical Society B, vol. 12, pp. 317-321, 1967.

[6] M. T. H. Tarafder, K.-B. Chew, K. A. Crouse, A. M. Ali, B. M. Yamin, and H.-K. Fun, "Synthesis and characterization of $\mathrm{Cu}(\mathrm{II}), \mathrm{Ni}(\mathrm{II})$ and $\mathrm{Zn}(\mathrm{II})$ metal complexes of bidentate NS isomeric Schiff bases derived from S-methyldithiocarbazate (SMDTC): bioactivity of the bidentate NS isomeric Schiff bases, some of their $\mathrm{Cu}(\mathrm{II}), \mathrm{Ni}(\mathrm{II})$ and $\mathrm{Zn}$ (II) complexes and the $\mathrm{x}$-ray structure of the bis[S-methyl- $\beta$ - $N$-(2-furylmethyl)methylenedithiocarbazato]zinc(II) complex," Polyhedron, vol. 21, no. 27-28, pp. 2683-2690, 2002.

[7] E. J. Larson and V. L. Pecoraro, "The peroxide-dependent $\mu 2-\mathrm{O}$ bond formation of $\left[\mathrm{Mn}^{(\mathrm{IV})} \mathrm{SALPN}(\mathrm{O})\right]_{2}$," Journal of the American Chemical Society, vol. 113, no. 10, pp. 3810-3818, 1991.

[8] I. Ramade, O. Kahn, Y. Jeannin, and F. Robert, "Design and Magnetic Properties of a Magnetically Isolated $\mathrm{Gd}^{\mathrm{III}} \mathrm{Cu}^{\mathrm{II}}$ Pair. Crystal Structures of $\left[\mathrm{Gd}(\mathrm{hfa})_{3} \mathrm{Cu}(\right.$ salen $\left.)\right]$, $\left[\mathrm{Y}(\mathrm{hfa})_{3} \mathrm{Cu}(\right.$ salen $\left.)\right],\left[\mathrm{Gd}(\mathrm{hfa})_{3} \mathrm{Cu}\right.$ (salen)(Meim)], and $\left[\mathrm{La}(\mathrm{hfa})_{3}\left(\mathrm{H}_{2} \mathrm{O}\right) \mathrm{Cu}(\right.$ salen $\left.)\right][\mathrm{hfa}=$ Hexafluoroacetylacetonato, salen $=\mathrm{N}, \mathrm{N}^{\prime}$-Ethylenebis(salicylideneaminato), Meim = 1-Methylimidazole]," Inorganic Chemistry, vol. 36, no. 5, pp. 930-936, 1997.

[9] N. Hoshino, "Liquid crystal properties of metal-salicylaldimine complexes. Chemical modifications towards lower symmetry," Coordination Chemistry Reviews, vol. 174, no. 1, pp. 77-108, 1998.

[10] L. Shi, W.-J. Mao, Y. Yang, and H.-L. Zhu, "Synthesis, characterization, and biological activity of a Schiff-base $\mathrm{Zn}$ (II) complex," Journal of Coordination Chemistry, vol. 62, no. 21, pp. 3471-3477, 2009.

[11] J. Zhao, B. Zhao, J. Liu, W. Xu, and Z. Wang, "Spectroscopy study on the photochromism of Schiff bases $N, N^{\prime}$-bis(salicylidene)1,2-diaminoethane and $N, N^{\prime}$-bis(salicylidene)-1,6-hexanediamine," Spectrochimica Acta A, vol. 57, no. 1, pp. 149-154, 2001.

[12] H. Carlsson, M. Haukka, A. Bousseksou, J.-M. Latour, and E. Nordlander, "Nickel complexes of carboxylate-containing polydentate ligands as models for the active site of urease," Inorganic Chemistry, vol. 43, no. 26, pp. 8252-8262, 2004.

[13] Y. S. Higasio and T. Shoji, "Heterocyclic compounds such as pyrroles, pyridines, pyrollidins, piperdines, indoles, imidazol and pyrazins," Applied Catalysis A, vol. 221, no. 1-2, pp. 197-207, 2001.
[14] L. Juhász, Z. Dinya, S. Antus, and T. E. Gunda, "A new approach for the synthesis of naturally occurring dihydrobenzo[ $b]$ furantype neolignans of potential biological activity," Tetrahedron Letters, vol. 41, no. 14, pp. 2491-2494, 2000.

[15] P. K. Coughlin and S. J. Lippard, "Copper(II) chemistry in hexaaza binucleating macrocycles: hydroxide and acetate derivatives," Journal of the American Chemical Society, vol. 106, no. 8, pp. 2328-2336, 1984.

[16] H. Ünver and Z. Hayvali, "Synthesis, spectroscopic studies and structures of square-planar nickel(II) and copper(II) complexes derived from 2-(Z)-[furan-2-ylmethyl]imino]methyl-6methoxyphenol," Spectrochimica Acta A, vol. 75, no. 2, pp. 782788, 2010.

[17] M. Shakir, A. Abbasi, M. Azam, and A. U. Khan, "Synthesis, spectroscopic studies and crystal structure of the Schiff base ligand $\mathrm{L}$ derived from condensation of 2-thiophenecarboxaldehyde and 3,3'-diaminobenzidine and its complexes with $\mathrm{Co}(\mathrm{II}), \mathrm{Ni}(\mathrm{II}), \mathrm{Cu}(\mathrm{II}), \mathrm{Cd}(\mathrm{II})$ and $\mathrm{Hg}(\mathrm{II})$ : Comparative DNA binding studies of $\mathrm{L}$ and its $\mathrm{Co}(\mathrm{II}), \mathrm{Ni}(\mathrm{II})$ and $\mathrm{Cu}(\mathrm{II})$ complexes," Spectrochimica Acta A, vol. 79, no. 5, pp. 1866-1875, 2011.

[18] Z. Hayvalı, M. Hayvalı, Z. Kılıc, T. H. kelek, and E. Weber, "New benzo-15-crown-5 ethers featuring salicylic Schiff base substitutions. Synthesis, complexes and structural study," Journal of Inclusion Phenomena and Macrocyclic Chemistry, vol. 45, no. 34, pp. 285-294, 2003.

[19] J. Ma, W.-Z. Fan, and L.-R. Lin, "A dinuclear zinc complex with (E)-4-dimethylamino- $\mathrm{N}^{\prime}$;-(2-hydroxybenzylidene)benzohydrazide," Acta Crystallographica Section E, vol. 67, no. 5, pp. m624-m625, 2011.

[20] A. Rahman, M. Choudhary, and W. Thomsen, Bioassay Techniques For Drug Development, Harwood Academic, Amsterdam, The Netherlands, 2001.

[21] W. J. Geary, "The use of conductivity measurements in organic solvents for the characterisation of coordination compounds," Coordination Chemistry Reviews, vol. 7, no. 1, pp. 81-122, 1971.

[22] M. J. Al-Jeboori, I. Omran, and J. Al-Dulaimi, "Formation of binuclear metal complexes withmultidentate Schiff-base oxime ligand: synthesis and spectral investigation," Ibn Al-Haitham Journal For Pure And Applied Science, vol. 24, no. 2, pp. 142-153, 2011.

[23] M. J. Al-Jeboori, A. Abdul Rahman, and S. Atia, "Synthesis and spectral studies on cobalt(II), nickel(II), copper(II), palladium(II), platinum(II, IV), zinc(II), cadmium(II) and mercury(II) complexes of (1, 2-diaminoethane-N, N-bis(2butylidine-3onedioxime," Ibn Al-Haitham Journal For Pure And Applied Science, vol. 18, no. 2, pp. 51-67, 2005.

[24] K. Nakomoto, Infrared Spectra of Inorganic and Coordination Compounds, John Wiley \& Sons, New York, NY, USA, 4th edition, 1996.

[25] M. J. Al-Jeboori, A. H. Al-Dujaili, and A. E. Al-Janabi, "Coordination of carbonyl oxygen in the complexes of polymeric $\mathrm{N}$-crotonyl-2-hydroxyphenylazomethine," Transition Metal Chemistry, vol. 34, no. 1, pp. 109-113, 2009.

[26] S. E. Livingston, J. H. Mayfield, and D. S. Moorse, "Thio derivatives of $\beta$-diketones and their metal chelates. Magnetic moments of some ruthenium(III) chelates of fluorinated Monothio- $\beta$-diketones," Australian Journal of Chemistry, vol. 28, no. 11, pp. 2531-2533, 1975.

[27] A. Z. El-Sonbati, A. A. El-Bindary, and A. A. Al-Sarawy, "Stereochemistry of new nitrogen containing heterocyclic aldehyde. IX. Spectroscopic studies on novel mixed-ligand complexes of 
Rh(III)," Spectrochimica Acta A, vol. 58, no. 12, pp. 2771-2778, 2002.

[28] R. M. Silverstein, Spectrometric Identification of Organic Compounds, John Wiley \& Sons, 7th edition, 2005.

[29] A. P. Lever, Inorganic Electronic Spectroscopy, Elsevier, New York, NY, USA, 2nd edition, 1984.

[30] B. N. Figgis, Introduction To Ligand Fields, Interscience Publishers, John Wiley \& Sons, New York, NY, USA, 1967.

[31] O. S. M. Nasman, " $\mathrm{N}_{2} \mathrm{~S}_{2}$-donor macrocycles with some transition metal ions: synthesis and characterization," Phosphorus, Sulfur and Silicon and the Related Elements, vol. 183, no. 7, pp. 1541-1551, 2008.

[32] M. M. Aly, A. O. Baghlaf, and N. S. Ganji, "Linkage isomerism of the oximato group: the characterization of some mono- and binuclear square planar nickel(II) complexes of vicinal oximeimine ligands," Polyhedron, vol. 4, no. 7, pp. 1301-1309, 1985.

[33] Z. H. Chohan, H. Pervez, K. M. Khan, A. Rauf, G. M. Maharvi, and C. T. Supuran, "Antifungal cobalt(II), copper(II), nickel(II) and zinc(II) complexes of furanyl-thiophenyl-, pyrrolyl-, salicylyl- and pyridyl-derived cephalexins," Journal of Enzyme Inhibition and Medicinal Chemistry, vol. 19, no. 1, pp. 85-90, 2004. 

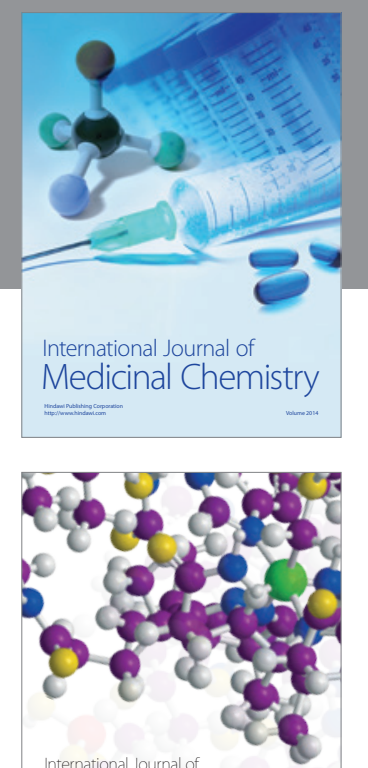

\section{Carbohydrate} Chemistry

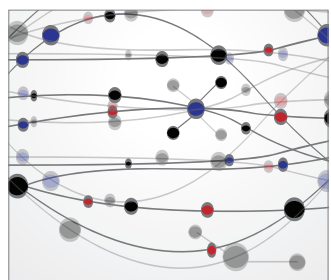

The Scientific World Journal
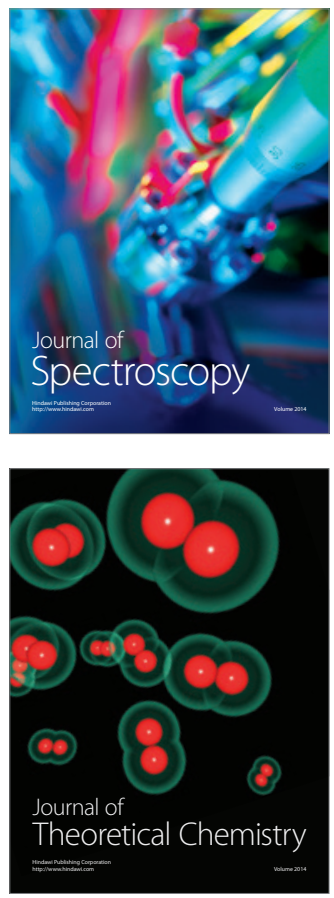
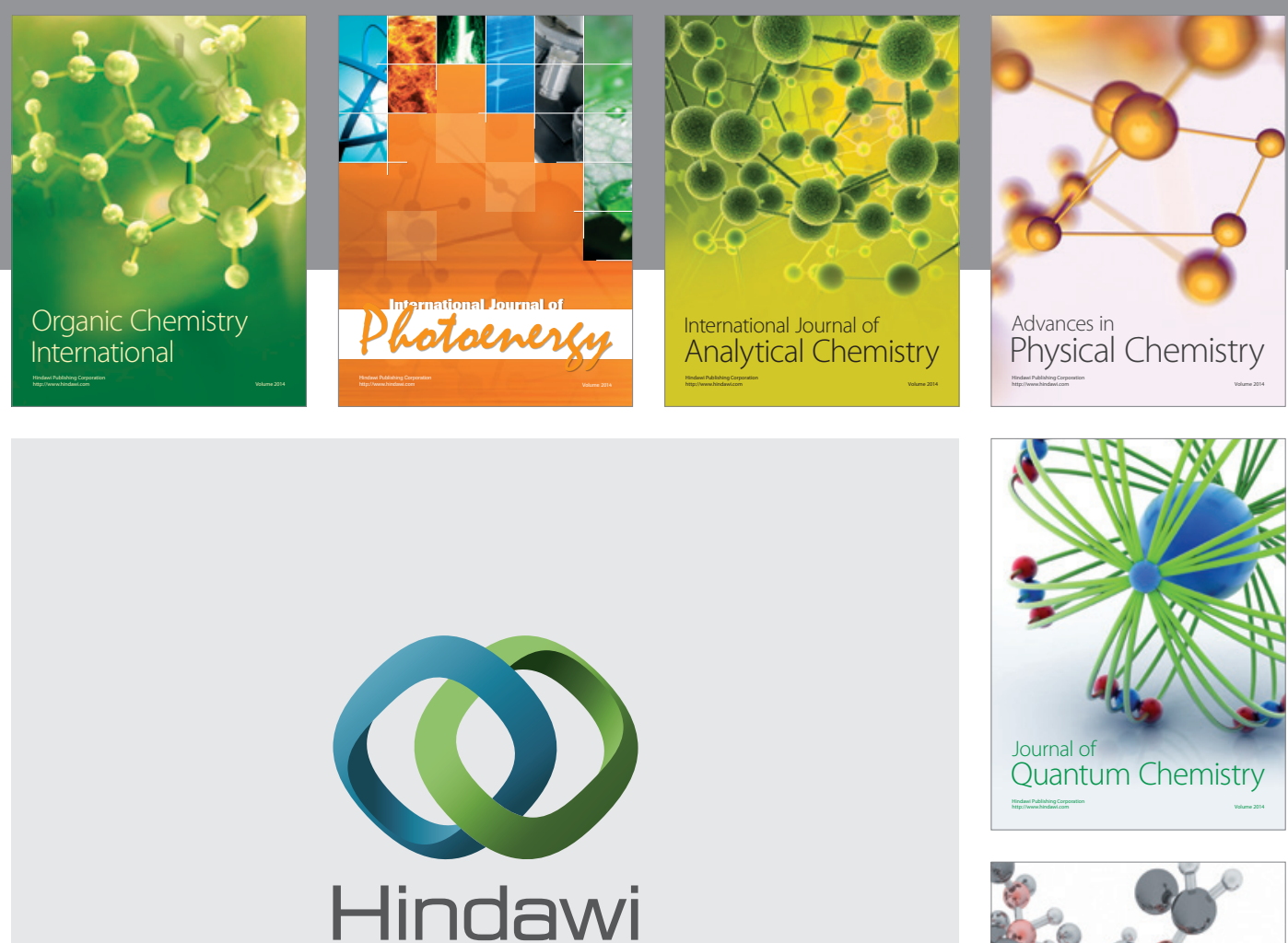

Submit your manuscripts at

http://www.hindawi.com

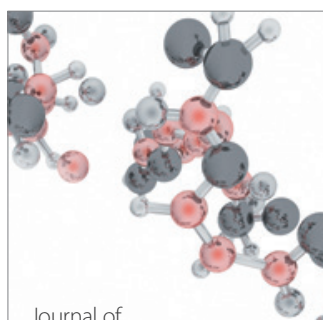

Analytical Methods

in Chemistry

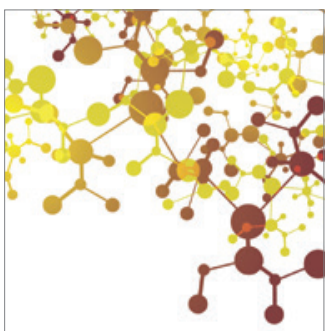

Journal of

Applied Chemistry

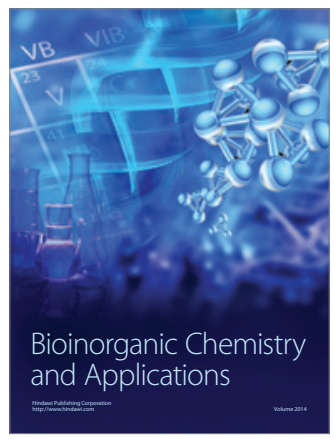

Inorganic Chemistry
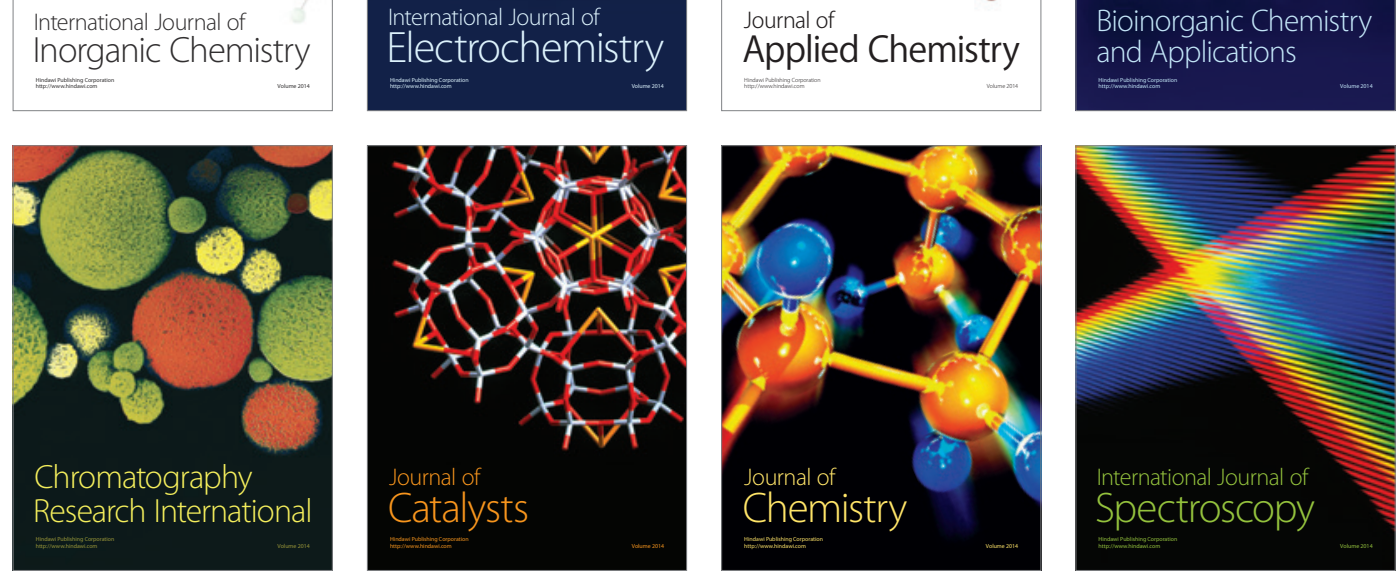